\title{
The poetic construction of the self
}

\section{Niamh O’Mahony}

\author{
School of English
}

"When I play with my cat, who knows if I am not a pastime to her more than she is to me?" - (Michel de Montaigne, 1576)

\section{Introduction}

It is particularly appropriate that an introduction to my research into the poetic constitution of the Subject should begin with a reflection on the relationship between a cat and her keeper. The statement quoted above presents the cat as a subject with the capacity to think and comprehend equal to that of her human. In this example, the French philosopher Michel de Montaigne extends that proposition by suggesting that the cat's consciousness might well lead her to perceive her owner as an amusement; "We entertain each other with reciprocal monkey tricks," he says, "if I have my time to begin or refuse, so has she hers". The chief philosophical question arising from Montaigne's meditation on feline consciousness is why we so readily and forthrightly disregard the possibility that the philosopher should indeed be "a pastime" to his cat; why are so unwilling to bestow upon an animal a consciousness at least comparable to that of a human? And what does it do to our relationship with that animal that she is not accorded some degree of the consciousness we accord to each other?

This invocation of the philosopher's cat derives directly from the opening pages of French philosopher Jacques Derrida's The Animal That Therefore I Am, and is referenced because it remains an incomparable articulation of the problem of self in philosophy. When the attribution of subjectivity to an individual continues to exert such a strong influence over ones expectations of life, and indeed the value placed on to that life, it is fundamental that the construction and attribution of subjectivity is understood as thoroughly as possible. To deny particular individuals or populations the same subject-hood we accord to each other encourages a set of behaviours and operations from the most uninformed and ignorant to the most unspeakably violent and inhumane.

Contemporary poetry offers vibrant approaches to this questioning of philosophical subjectivity. Tracing the history of criticism and its various affirmations of the authority of the poet, the poem, and the reader, this study engages a diversity of poetries in examining the development of the subject. Aligning poetry with philosophy in an investigation into the constitution of the subject enhances philosophical understanding of and writing about the 
category of "the subject," while also invigorating discussion of the relations between the text and the person in poetry criticism.

\section{Philosophy}

\section{What is a philosophical Subject, and where did it come from?}

The Subject has a long and complex history in continental philosophy, and is dated back to works by the 'Father of Modern Philosophy,' Rene Descartes (1596-1650). Descartes' theorising on the Subject produced one of the most famous phrases in modern philosophy, "I think, therefore I am." Put simply, "I think, therefore I am" asserts that cognition is the primary condition of being; to think, or to cognize, is to be a self.

As critical thinking developed, the philosophical subject gained currency as a method of categorizing the many different beings in the world. The authority and significance of the being was measured according to its perceived consciousness, and as consciousness was believed to be the defining feature of humanity, the human being was granted the highest position. The classification of life in respect to cognition has been invoked by a vast variety of writers and philosophers in the following years, and has been intrinsic to public debates regarding man's dominion over nature since before the Industrial Revolution.

\section{How has the philosophy of the Subject changed over time?}

The purpose and function of the Subject varies from philosopher to philosopher and from text to text. Historically, philosophers used the concept because it offered them a lowest common denominator for discussion and debate of perceived wider philosophical questions. Others used it to assert man's authority to exert control over other beings and objects as the most superior of Subjects. Over the past century, the focus has shifted from invocations of the Subject as a critical tool in philosophical writing, to a more considered examination of the experience of Subject-hood. Moving towards an analysis of the relationship between Subjects, Emmanuel Levinas discussed the striking differences of one Subject and an 'Other'. For Levinas, philosophical Subjectivity always manifested itself as "welcoming the Other, as hospitality." It is in the interaction of one Subject and an "Other" that "the idea of infinity is consummated," Levinas says, because the fundamental differences between Subjects makes it impossible that we should ever fully know or understand one another

French philosopher Jacques Derrida developed Levinas' understanding of the Subject further. He looked at the treatment of animals in society to learn more about the development and application of human selfhood or Subjectivity. For Derrida, the most important question was not whether an animal has reason or not, but whether it could suffer. By replacing 
cognition with suffering as the primary condition of being, Derrida challenged the logical justifications of decisions and policies, whether referring to the ritualised slaughter of animals in abattoirs or the massacre of Jews, gypsies and homosexuals in Nazi gas chambers. Derrida complicated Levinas' philosophising by showing that the "hospitality" characterising Levinas' ethical Subjectivity is available only to the individual already collectively acknowledged and recognised as a Subject; in other words, you are ethically responsible to another human Subject only if they are already acknowledged and recognised as a Subject.

\section{How will the concept of the Subject be treated in this study?}

Modern understandings of the Subject can be extended by investigating the complex interrelations of poet, poem and reader in the work of the Cambridge poet J.H. Prynne. This analysis interrogates conventional arguments about the authority of the poet in deciding the meaning of a poem, and its radical undermining of the validity of a reader's interpretation and understanding. Transposing the philosophical discussion of the Subject into the study of poetry generates new insights into the construction and application of the category of the Subject as it queries traditional conceptions of this philosophical concept. Reading Prynne's poetry through the lens of philosophical Subjectivity invigorates the critical reception of the poet's work today, while also offering an example for the innovations in interpretation and understanding it hopes to generate. The poetic consideration of subjectivity is a support to rather than a replacement of philosophical work.

\section{Poetry}

The following reading of the poem "For A Quiet Day" offers an example of the discussion of Subjectivity within contemporary poetry. Poetic analyses typically start with an acknowledgement of the difficulty of attributing a single, unified meaning to a linguistic construct where each word is loaded with diverse etymologies and multiple meanings. J.H. Prynne's poems can be interpreted as investing in the debate around subjectivity because they undermine the traditional role of the reader as passive receiver of the work.

Prynne's poetry challenges the understanding of the poem as holding a decipherable meaning which the reader or critic must unfold. It encourages the reader to disregard the idea that a poem should present one stable meaning, and asks instead for what Prynne calls a reading of "maximum focused intelligence and passion." This analysis counteracts the frequent condemnations of this poetry as difficult and obscure, finding instead a particular generosity and reserve. 


\section{For a Quiet Day}

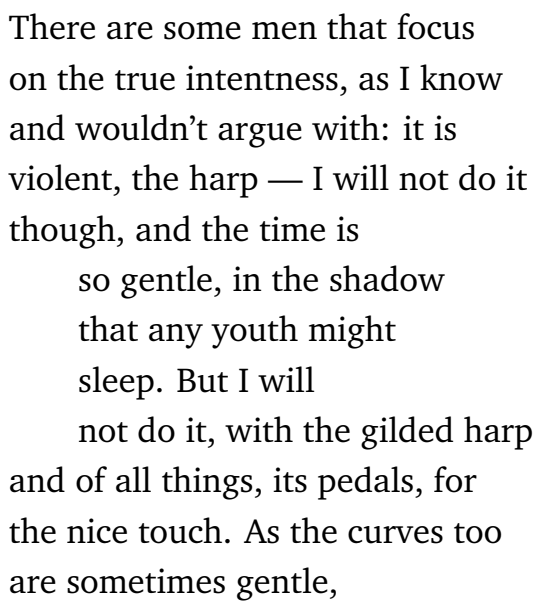

(J.H. Prynne, Poems, 2005)

These lines come from the opening section of "For a Quiet Day," the eighteenth poem in Prynne's 1969 collection The White Stones. On one level, this is a poem of resistance to the traditional assertion of the poet as authority on the meaning of the text and the manner in which it undermines the reader. As an ode, a poetic form of address, "For A Quiet Day" addresses those "men" who choose to "focus" on "true intentness," or meaning of a work of art, criticising it as time spent "in the shadow" said to be "so gentle" that "any youth might/ sleep". This crude construction of art as "gilded harp" with "pedals, for/ the nice touch," affirm the artist's control over the dissemination, whereby form and style, like "curves" that are "sometimes gentle," lull the reader into unwitting agreement. Prynne's poem disrupts conventional orientations of the reader and inaugurates alternative perspectives on subjectivity in contemporary society.

Thomas Butler offers an admirable reading of this poem in his unpublished $\mathrm{PhD}$ dissertation "Writing at the Edge of the Person: Lyric Subjectivity in Cambridge Poetry, 19661993." Butler argues that "For a Quiet Day" is the articulation of the Prynne's stance on poetic and philosophical Subjectivity. Such poems are said to demand complex engagement by the reader in which she or he is confronted with an array of disparate rhetorics "which block an easily consumable meaning and instead require the reader to remain in the space of the poem." Compelling the reader to occupy the poem in this way implies that the reader acknowledge and interact with others and "entertain what is discordant and other to it," thus challenging the prejudices and preconceptions of the individual Subject. Prynne is described as rejecting the singularity of "intentness," or meaning in poetry, comparing it to the "gilded harp" which is "always too/fine, too hopeless." As Butler explains, "poetry marked by "intentness" is characterized by a Subject who is isolated from experience and by transparent language_or, just the kind of poetry Prynne opposes."

It is just these kinds of digressions in language and meaning that redefine the responsibilities of the reader of Prynne's poetry, and thus of the category of reader as subject. His poems demand that the reader engage with and decide upon the meaning of the 
poem rather than uncovering a predetermined understanding. J.H. Prynne's reflections on being "rather frequently accused of having more or less altogether taken leave of discernible sense" are indicative of the particularly complex convolutions of sound and sense that characterize his poetry. The fact that he affirms these criticisms as "more or less true" demonstrates the progression of Prynne's poetry, moving away from what he says "for so long has seemed the arduous royal road into the domain of poetry ("what does it mean?")."

\section{Conclusion}

The radical restructuring of relations between poet, poem and reader is achieved as result of the particular poems and collections, and the manner in which they are critically analysed. Transferring philosophical debate of subjectivity into the domain of the poetic invigorates understandings of authorial power and the critical production of meaning in poetry. It also extends philosophical debates through a more creative, imaginative trajectory, generating new ways of responding to old issues and debates. While discussions of the Subject continue to provoke strong reactions in philosophical circles today, the real consequences of this concept are manifested in more real and often violent ways in wider society, and it is for this reason that innovative analyses such as this are most important.

Niamh O'Mahony is a second year doctoral candidate under the supervision of Professor Graham Allen. She would like to acknowledge the support of the Irish Research Council for the Humanities and Social Sciences and the UCC William J Leen Fund. 